\title{
Simultaneous antibacterial and anticoagulant properties of polypropylene non-woven textiles
}

\section{Elaboration d'un textile polypropylène non-tissé présentant simultanément des propriétés antibactériennes et anticoagulantes}

\author{
Maude Jimenez ${ }^{1}$, Stéphanie Degoutin ${ }^{2}$, Séverine Bellayer ${ }^{1,3}$, Feng Chai ${ }^{4}$, \\ Nicolas Blanchemain ${ }^{4}$ and Christel Neut ${ }^{5}$ \\ 1 UMET-ISP, UMR 8207, ENSCL, BP. 90108, 59652 Villeneuve d'Ascq, France \\ 2 UMET-ISP, UMR 8207, Université Lille Nord de France, 59655 Villeneuve d'Ascq, France \\ ${ }^{3}$ ENSCL, Service microsonde, BP. 90108, 59652 Villeneuve d'Ascq Cedex, France \\ 4 INSERM U1008, Université Lille Nord de France, 59006 Lille, France \\ 5 INSERM U995, Université Lille Nord de France, 59006 Lille, France
}

\begin{abstract}
The aim of this work was to prepare a non-woven Polypropylene (PP) textile functionalized with bioactive molecules to improve simultaneously its anticoagulation and antibacterial properties. The immobilization of either heparin (anticoagulation agent) or gentamicin (aminoglycoside antibiotic) was already proven to be effective on non-woven PP textiles. This work details how we managed to immobilize both gentamicin and heparin on the textile [1]. The immobilization times were studied in order to determine the best compromise between cytocompatibility, anticoagulant effect and antimicrobial activity.

Résumé. Cetté étude décrit le procédé de fonctionnalisation d'un textile polypropylène (PP) non-tissé afin d'améliorer à la fois ses propriétés antibactériennes et anticoagulantes. Dans des précédents travaux, l'immobilisation soit de l'héparine (agent anticoagulant), soit de la gentamicine (agent antibiotique aminoglycoside) a déjà été reportée. Des effets respectivement anticoagulants et antibactériens ont été obtenus. Cette étude décrit la façon d'immobiliser ces deux principes actifs sur un même textile. L'effet des temps d'imprégnation sur les propriétés antibactériennes et anticoagulantes a été étudié afin d'obtenir le meilleur compromis possible en termes de cytocompatibilité, effet anticoagulant et activité antimicrobienne.
\end{abstract}

\section{INTRODUCTION}

Biomaterials were developed to preserve the integrity and life comfort of patients suffering from intense functional deficiencies or burn/injury victims. Nowadays, in addition to biocompatibility, the interest in research on biomaterials lies in several properties such as bioactivity [2]. Indeed, polymer implants used in biomedical field may still lead to post-operative risks at the implant/biological tissue interface. Moreover, they must be coupled to an additional therapeutic treatment (drug administration, injections...). Those active principles are carried through biological fluids to the healing site, thus the real quantity of effective drug is lower than the introduced one.

Current solutions (drug delivery systems, tissue engineering...) are efficient, but still present some issues [3]. One idea would be to confer to implants new therapeutic properties adapted to these issues, which could be obtained by the immobilization of bioactive molecules.

These ones would be fixed via covalent bonds onto the support previously treated to allow the immobilization reaction. The long term efficiency of the implants would be widely improved, in comparison to drug delivery systems for example.

Among consequences of the implantation of a biomaterial, immediate response is the reaction of blood in contact with the surface of the implant. Resulting coagulation may hinder the integration and function of the implant. Hemocompatible coatings were developed to prevent those adverse reactions, especially through the immobilization of heparin $[4,5]$. Bacterial infection is also a major issue for implanted biomaterials. Surface modifications have been studied to avoid the bacterial colonization of synthetic materials after surgery, with the immobilization of antibiotics [6], silver particles [7], antimicrobial peptides [8] or polysaccharides such as chitosan [9]. In this context, the simultaneous immobilization of several drugs would confer multiple therapeutic activity and therefore an added value to the implant. We present in this paper our results concerning the immobilization of an anticoagulant molecule (heparin) and an aminoglycoside antibiotic (gentamicin) at the same time on a nonwoven PP surface, for a combined therapeutic activity of the obtained biomaterials.

\section{EXPERIMENTAL METHODS}

The method to covalently graft heparin or gentamicin on a non-woven PP textile was previously reported: a spacer (acrylic acid, AA, Acros) is grafted onto PP using a low pressure cold argon plasma process. The immobilization of either heparin $(5000 \mathrm{UI} / \mathrm{mL}$, Choay) or gentamicin ( $80 \mathrm{mg} / 2 \mathrm{~mL}$,PanPharma) on AA-grafted PP (PP-g-AA) was reported in the same paper [1]. For heparin immobilization, the anticoagulant effect is improved especially when heparin is covalently bound through a carbodiimide (EDC) activation of $-\mathrm{COOH}$ 
Table 1. List of PP-g-AA samples containing heparin and gentamicin.

\begin{tabular}{|c|c|c|c|}
\hline $\begin{array}{l}\text { Sample } \\
\text { name }\end{array}$ & $\begin{array}{l}\text { EDC } \\
\text { reaction } \\
\text { time }\end{array}$ & $\begin{array}{l}\text { Heparin } \\
\text { immobilization } \\
\text { time }\end{array}$ & $\begin{array}{l}\text { Gentamicin } \\
\text { immobilization } \\
\text { time }\end{array}$ \\
\hline PPgAA-G24 & - & - & $24 \mathrm{~h}$ \\
\hline PPgAA-EDC-G24 & $2 \mathrm{~h}$ & - & $24 \mathrm{~h}$ \\
\hline PPgAA-H24 & - & $24 \mathrm{~h}$ & - \\
\hline PPgAA-EDC-H24 & $2 \mathrm{~h}$ & $24 \mathrm{~h}$ & - \\
\hline PPgAA-EDC & & & \\
\hline $\begin{array}{l}-\mathrm{H} 24-\mathrm{G} 24 \\
\text { PPgAA-EDC }\end{array}$ & $2 \mathrm{~h}$ & $24 \mathrm{~h}$ & $24 \mathrm{~h}$ \\
\hline$-\mathrm{H} 24-\mathrm{G} 8$ & $2 \mathrm{~h}$ & $24 \mathrm{~h}$ & $8 \mathrm{~h}$ \\
\hline PPgAA-EDC & & & \\
\hline -H24-G4 & $2 \mathrm{~h}$ & $24 \mathrm{~h}$ & $4 \mathrm{~h}$ \\
\hline PPgAA-EDC & & & \\
\hline$-\mathrm{H} 24-\mathrm{G} 1$ & $2 \mathrm{~h}$ & $24 \mathrm{~h}$ & $1 \mathrm{~h}$ \\
\hline PPgAA-EDC & & & \\
\hline -H8-G24 & $2 \mathrm{~h}$ & $8 \mathrm{~h}$ & $24 \mathrm{~h}$ \\
\hline
\end{tabular}

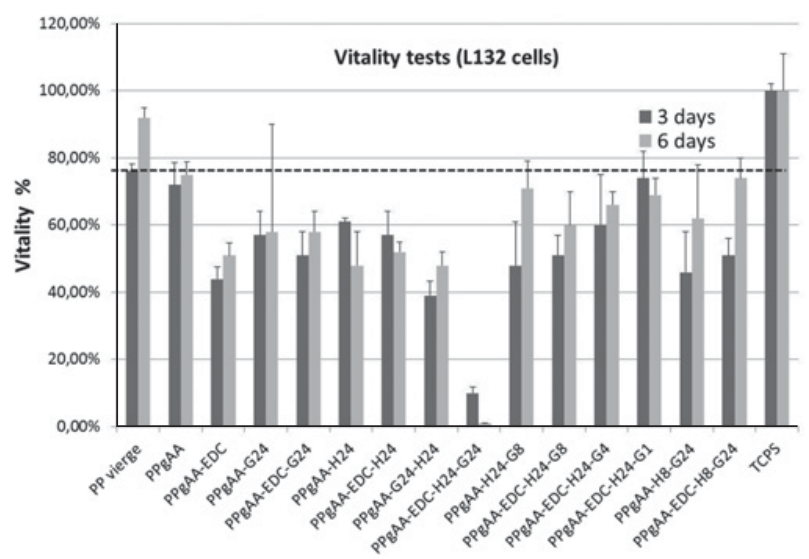

Figure 1. 1: L132 cells vitality after 3 and 6 days on the PPgAAEDC-Hx-Gy samples.

groups. On the other hand, a strong antimicrobial activity is observed when gentamicin is linked through ionic bonds, allowing its diffusion into the medium. In this work, samples with one or two immobilized biomolecules (with or without EDC) were prepared by respectively one or two successive immersions. Heparin was covalently fixed in a first step, followed by gentamicin.

Table 1 presents all the samples prepared in this study. Samples were named PPgAA-EDC-H $x-\mathrm{G} y$, with $x$ and $y$ corresponding to the impregnation time in heparin and gentamicin respectively. Impregnation times were comprised between 1 and $24 \mathrm{~h}$.

The presence and activity of biomolecules was assessed through clotting assays and Kirby-Bauer tests. The cytocompatibility was demonstrated using epithelial L132 cells.

\section{RESULTS AND DISCUSSION}

Vitality tests on L132 cells, carried out on samples grafted with both heparin and gentamicin show cell vitality up between $10 \%$ and $78 \%$ (Fig. 1). The best value is obtained for the lowest gentamicin rate, related to short impregnation time.

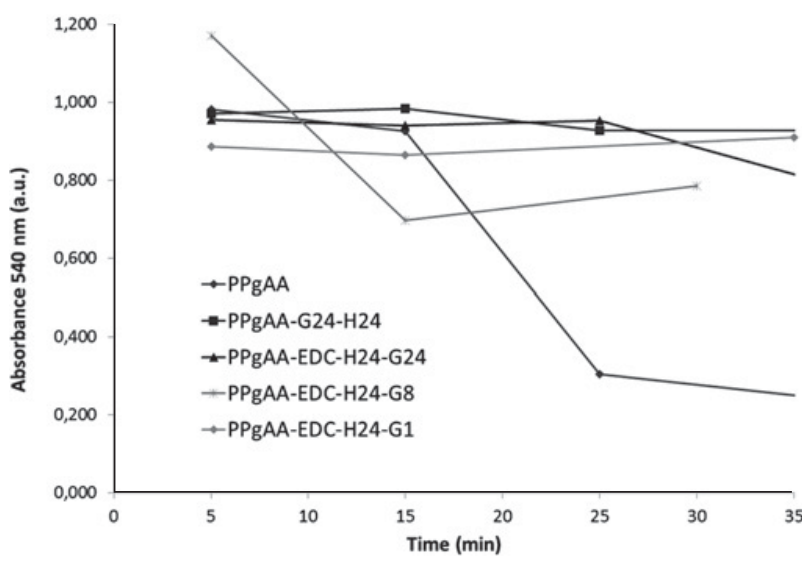

Figure 2. Free haemoglobin released from some PPgAA-EDCHx-Gy samples versus time.

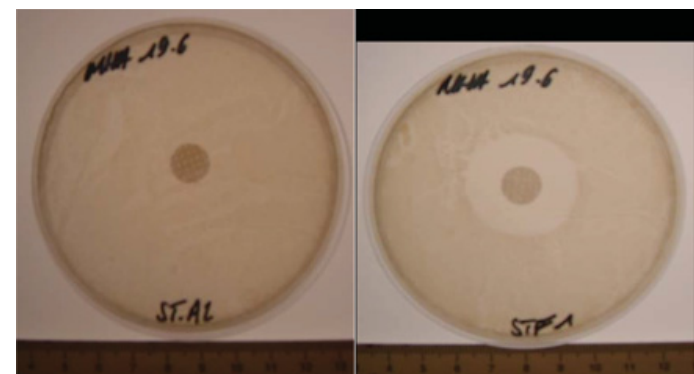

Figure 3. Kirby Bauer tests after $24 \mathrm{~h}$ of contact with S. aureus for PPgAA (left) and PPgAA-EDC-H24-G8 (right).

The titration of free haemoglobin on samples put in presence of blood (clotting assays) showed that the samples containing heparin and gentamicin had a coagulation time higher than $30 \mathrm{~min}$, when the anticoagulant activity of PP-g-AA control was negligible after $15 \mathrm{~min}$. Some of these test results are reported in Figure 2

The best anticoagulant behaviour was obtained when heparin immobilization step lasted $24 \mathrm{~h}$.

Kirby-Bauer test showed inhibition diameters for biomolecule-immobilized samples after $24 \mathrm{~h}$ of contact with $S$. aureus. For example, an inhibition diameter of $36 \mathrm{~mm}$ for the sample PPgAA-EDC-H24-G8 was observed (Fig. 3). Bacterial adhesion was also measured and a bacterial reduction of over $99.99 \%$ was measured after $24 \mathrm{~h}$.

Finally, the best compromise was obtained for PPgAAEDC-H24-G1: on this sample a cell vitality of 74\% after 3 days and $69 \%$ after 6 days is observed, and a good cell proliferation is reported (more than $75 \%$ after 3 days). This sample also still presents an excellent anticoagulation activity after 40 minutes and shows a reduction effect on bacterial adhesion of $99,99997 \%$ (i.e. $5 \log$ ) compare to PP-g-AA as well as an inhibition diameter of $2.4 \mathrm{~cm}$.

\section{CONCLUSION}

The immobilization of both heparin and gentamicin on PP samples was carried out successfully. The obtained cytocompatible material showed at the same time very good antibacterial and anticoagulant properties. These 
promising results obtained under static conditions need to be confirmed by dynamic studies to mimic in vivo conditions. The functionalized PP substrate has potential applications such as wound care, thanks to its simultaneous anticoagulant and antimicrobial properties.

\section{References}

[1] S. Degoutin, M. Jimenez, M. Casetta, S. Bellayer, F. Chai, N. Blanchemain, C. Neut, I. Kacem, M. Traisnel, B. Martel, Biomedical Materials, 2012, 7, 035001.

[2] B.M. Holzapfel, J.C. Reichert, J.-T. Schantz, U. Gbureck, L. Rackwitz, U. Nöth, F. Jakob, M. Rudert, J. Groll, D.W. Hutmacher, Advanced Drug Delivery Reviews, 2012, In Press.

[3] P.P. Karmali, D. Simberg, Expert Opinion on Drug Delivery, 2011, 8, 343-357.
[4] C. Werner, M.F. Maitz, C. Sperling, J. Mater. Chem., 2007, 17, 3376-3384.

[5] J. Jin, W. Jiang, Q. shi, J. Zhao, J. Yin, P. Stagnaro, Applied Surface Science, 2012, 258, 5841-5849.

[6] K. Junge, R. Rosch, U. Klinge, C. Krones, B. Klosterhalfen, P.R. Mertens, P. Lynen, D. Kunz, A. Preiß, H. Peltroche-Llacsahuanga, V. Schumpelick, Biomaterials, 2005, 26, 787-793.

[7] M.L.W. Knetsch, L.H. Koole, Polymers, 2011, 3, 340366.

[8] G. Gao, D. Lange, K. Hilpert, J. Kindrachuk, Y. Zou, J.T.J. Cheng, M. Kazemzadeh-Narbat, K. Yu, R. Wang, S.K. Straus, D.E. Brooks, B.H. Chew, R.E.W. Hancock, J.N. Kizhakkedathu, Biomaterials, 2011, 32, 3899-3909.

[9] S. Saxena, A.R. Ray, A. Kapil, G. Pavon-Djavid, D. Letourneur, B. Gupta, A. Meddahi-Pellé, Macromolecular Bioscience, 2011, 11, 373-382. 